\title{
ДІЯЛЬНІСНИЙ ПІДХІД У ФОРМУВАННІ ЕКОЛОГІЧНОї КОМПЕТЕНТНОСТІ МАЙБУТНІХ УЧИТЕЛІВ НОВОї УКРАÏнСЬКОї ШКОЛИ
}

\author{
T. С. Нінова, В. П. Шnак
}

\section{THE ACTIVITY APPROACH TO THE DEVELOPMENT OF ECOLOGICAL COMPETENCE IN FUTURE TEACHERS OF THE NEW UKRAINIAN SCHOOL}

\author{
T. Ninova, V. Shpak
}

\begin{abstract}
Висвітлено проблему застосування діяльнісного підходу в формуванні екологічної компетентності майбутніх учителів Нової української школи. Проведено аналіз наукових праць сучасних зарубіжних і вітчизняних дослідників проблеми екологічної освіти майбутніх учителів для встановлення співвідношення понять «екологічна освіта», «екологічна культура» та «екологічна компетентність». При визначенні структури професійної компетентності вчителя Нової української школи ми виходили $з$ того, що всі різновиди компетентностей, у тому числі й екологічна, є видовими поняттями по відношенню до родового поняття «компетентність», і мають однакову структуру, яка включає когнітивний, діяльнісний і особистісно-мотиваційний компоненти. Своєю чергою, компоненти екологічної компетентності майбутніх учителів Нової української школи розглянуто в пояснювально-аналітичному, прогностичному, процесуальному, діяльнісному і ціннісно-орієнтаційному аспектах. Для проведення експериментального дослідження 3 визначення сформованості екологічної компетентності майбутнього вчителя Нової української школи шляхом застосування в освітньому процесі системи практико зорієнтованих завдань і вправ екологічного спрямування обрано групи студентів третього і четвертого курсів денної форми навчання спеціальності 013 «Початкова освіта» Черкаського національного університету імені Богдана Хмельницького (усього близько 80 осіб). Застосовано такі методи дослідження, як тестування, самооцінювання, анкетування. Оцінювання проводилося в балах за шкалою від 1 до 10. За результатами дослідження, найкраще студентам третього курсу дається пояснення екологічних процесів у довкіллі, володіння екологічними поняттями і сучасними технологіями проведення еколого-просвітницької роботи. Натомість високих результатів у формуванні екологічної компетентності у студентів четвертого курсу досягнуто за іншими показниками: розуміння особистої відповідальності за екологічний стан довкілля; здатність передбачати екологічні зміни середовища при антропогенному втручанні; оволодіння методами проведення екологічних досліджень. Доцільність вибору в ході дослідження діяльнісного підходу підтверджено
\end{abstract}


показниками процесуального (передбачає можливість знаходження процедури або способу діяльності, придатних для розв'язання екологічної проблеми) і діяльнісного (втілюється переважно в ході проектної та наукової діяльності) аспектів.

Ключові слова: екологічна компетентність, екологічна освіта, екологічна культура, діяльнісний підхід, майбутні вчителі, Нова українська школа.

The problem of applying the activity approach to the development of ecological competence in future teachers of the New Ukrainian School is highlighted. The analysis of scientific works of modern foreign and domestic researchers of the problem of environmental education of future teachers are conducted to establish the relation between the concepts of "environmental education", "ecological culture" and "ecological competence". In determining the structure of professional competence of the teacher at the New Ukrainian School, we proceeded from the assumption that all kinds of competencies, including environmental ones, are specific concepts concerning the generic concept of "competence". They have the same structure, which includes the cognitive, activity, and personality-motivational components. In turn, the components of environmental competence of future teachers of the New Ukrainian School are considered in the explanatory-analytical, prognostic, procedural, activity, and value-orientation aspects. Groups of third and fourth-year full-time students of specialty 013 "Primary education" of Bohdan Khmelnytsky Cherkasy National University (total of about 80 persons) participated in the experimental study. The development of ecological competence of the New Ukrainian School future teacher is determined by the system of oriented tasks and exercises of ecological orientation applied in the educational process. Such research methods as testing, self-assessment, questionnaire are applied. According to the results of the study, the best students of the third year explained environmental processes in the environment, the possession of environmental concepts, and modern technologies of environmental education. Instead, high scores in fourth-year students' environmental competency are achieved by other indicators: understanding of personal responsibility for the environmental state of the environment; the ability to predict environmental changes in anthropogenic intervention; mastering environmental research methods. The appropriateness of the choice during the study of the activity approach is confirmed by the procedural indicators, which provide an opportunity to find a procedure or method of action that is suitable for solving an environmental problem, and activity aspects embodied mainly in the design and scientific activities.

Keywords: environmental competence, environmental education, environmental culture, action approach, future teachers, New Ukrainian School.

Постановка проблеми. Початок третього тисячоліття ознаменований посиленою увагою до формування в молодого покоління екологічної культури і свідомості, поінформованості про екологічну ситуацію в Україні та світі, обізнаності з можливими шляхами розв'язання різних екологічних проблем, а також із концептуальними підходами до збереження біосфери. Таку роботу доцільно організовувати 3 перших днів навчання в закладі загальної середньої освіти з молодшими школярами, щоб забезпечити своєчасне здобуття ними «елементарних знань про природу та взаємозв'язки в ній, взаємодію та взаємовплив людини i 
природи; розуміння погіршення стану навколишнього середовища внаслідок нераціональної господарської діяльності та особистої причетності до екологічних проблем; розвиток ціннісного ставлення до природи як джерела задоволення естетичних, комунікативних, пізнавальних, рекреаційних та інших потреб особистості; формування елементів здорового способу життя та навичок екологічно доцільної поведінки» (Концепція екологічної освіти України, 2001).

Оскільки одним із пріоритетних напрямів нині стає «формування поколінь із новою екологічною культурою, новим екологічним світоглядом на принципах гуманізму, екологізації мислення, міждисциплінарної інтеграції, історизму та системності 3 метою збереження і відновлення природи України та ii біологічного різноманіття» (Концепція екологічної освіти України, с. 2), то особлива відповідальність має покладатися на вчителя Нової української школи зі сформованою в нього екологічною компетентністю. Однак, як показують попередні дослідження (Саєнко, 2015; Граматик, 2017; Хроленко, 2007), більшість студентів уважають себе непричетними до розв’язання проблем довкілля, недостатньо готові до діяльності 3 формування екологічної культури й екологічного мислення учнів, а також не вміють застосовувати набуті екологічні знання на практиці.

На нашу думку, така недостатня увага до екологічного складника в навчальних програмах фахових дисциплін, ігнорування необхідності формування екологічної компетентності при вивченні професійно спрямованих предметів циклу загальної підготовки лише підсилюють екологічні проблеми сучасності регіонального і глобального рівнів та їх причини. Відсутність екологічного матеріалу під час проведення практичних i лабораторних занять як із природничих, так i 3 гуманітарних наук, ігнорування ролі кожної людини та іiі впливу на довкілля гальмують вивчення екологічних проблем своєї місцевості й реальної природоохоронної діяльності майбутніми вчителями Нової української школи, на яких покладається особлива відповідальність за збереження довкілля (Нінова, 2017).

Аналіз основних досліджень і публікацій, в яких започатковано розв'язання даної проблеми. Аналіз праць зарубіжних дослідників дозволяє стверджувати, що проблема формування екологічної компетентності майбутніх учителів поки що залишається поза їхньою увагою. Однак, нам імпонує позиція Дж. Джудсон - викладача Університету Саймона Фразера, яка у своїй статті розглядає екологічне мислення в контексті виокремлених із слів розумових образів, що можуть 
покращити вивчення міждисциплінарного змісту екологічної освіти, і як це допоможе учням розвинути екологічне розуміння - «глибоке відчуття зв'язку з живим світом і турботу про те, щоб змінити життя в ньому» (Judson, 2004). Посилаючись на праці Е. Ейснера i К. Егана, учена пропонує обгрунтування більш повного вивчення ментальних образів у процесі навчання і доходить до висновку про значущість і привабливість шкільного досвіду, що грунтується на творчій взаємодії учнів і вчителів 3 урахуванням змісту освітніх програм.

Не менш цікавою видається публікація викладача Університету Юта A. Ріголона (Rigolon, 2012), який намагається органічно поєднати ознайомлення школярів 3 екологічною літературою для адекватної соціалізації в соціумі й вироблення в них відповідної компетентності.

Серед сучасних напрямів розроблення проблематики екологічної освіти варто зазначити: теоретико-методичні аспекти формування екоетичної позиції майбутнього вчителя у процесі професійно-педагогічної підготовки (Александрович, 2011); особистісні якості, сформованість яких є показником розвитку еколого-валеологічної культури майбутнього вчителя (Бойчук, 2010); когнітивний компонент еколого-правової компетентності майбутнього вчителя, що містить сукупність загальнокультурних, загальнонаукових і спеціальних знань, а також знань з педагогіки та психології, сутність еколого-правових знань, що необхідні для оволодіння високим рівнем еколого-правової компетентності (Глухов, 2011); комплексний міждисциплінарний характер системи екологічної освіти 3 диференціацією, яка залежить від професійної орієнтації (Хоботова, Уханьова, Даценко та Сгорова, 2010).

Різні аспекти професійної підготовки майбутніх учителів початкової школи в галузі екологічної освіти і виховання учнів останнім часом активно розробляють учені А. Крамаренко (2015), Н. Граматик (2017), М. Хроленко (2007).

На сучасному етапі педагогічну діяльність учителів початкової школи в галузі екологічної освіти і виховання учнів розуміють як інтегративну, цілісну, багатоаспектну, спрямовану на формування особистісних якостей молодших школярів, що вступає у протиріччя 3 практикою підготовки майбутніх учителів у закладах вищої освіти. Зазначимо, що до цього часу в закладах вищої освіти домінує предметна система навчання, результатом такої організації освітнього процесу $є$ недостатній рівень сформованості екологічної компетентності майбутніх 
учителів Нової української школи, що проявляється як у недостатній умотивованості їх до здійснення екологічної освіти і виховання учнів, так і методичній непідготовленості до діяльності в цій галузі.

Це і визначило мету підготовки статті, що полягає у з'ясуванні ефективності застосування в освітньому процесі системи практико зорієнтованих завдань і вправ екологічного спрямування як одного зі шляхів реалізації діяльнісного підходу в формуванні екологічної компетентності майбутніх учителів Нової української школи.

Виклад основного матеріалу. Нині найбільш обгрунтованою та найчастіше вживаною $є$ чотирикомпонентна структура змісту освіти за I. Лернером, яка включає: інформаційний компонент - знання про природу, суспільство, техніку, людину, а також про способи діяльності; діяльнісний компонент - досвід реалізації способів діяльності, що разом зі знаннями втілюється у практичних та інтелектуальних уміннях і навичках; творчий компонент - досвід пошукової діяльності, готовність до розв'язування нових проблем; ціннісний компонент - сукупність етичних правил і норм, досвід емоційно-ціннісного ставлення до дійсності, який виявляється у відповідній моделі поведінки (Лернер, 1981).

Н. Пустовіт, досліджуючи дефініції понять «екологічна культура» та «екологічна компетентність», доходить до висновку про складність їх співвідношення, що виходить за межі причинно-наслідкового зв'язку «екологічна компетентність - екологічна культура». Науковець уважає, що поняття «компетентність» дозволяе акцентувати увагу на предметнодієвому компоненті, що передбачає оволодіння комплексною процедурою застосування знань i вмінь для розв'язання актуальних, зокрема, екологічних завдань. Тобто, компетентність інтегрує внутрішні й зовнішні компоненти екологічної поведінки, відображаючи не тільки знання про те, як діяти, а й конкретні вміння застосовувати це знання в певній екологічній ситуації, та орієнтує на вироблення власних моделей поведінки в різних ситуаціях, їх авторську апробацію, адаптацію до ціннісних орієнтацій особистості. Однак, екологічна культура не завжди прив'язана до ситуації й може розглядатися як духовна основа, ціннісносвітоглядний орієнтир, що визначає вибір рішення, спрямованість дії. У той самий час, компетентність узагальнює діяльнісно-практичні компоненти екологічної культури, грунтується на знаннях, різноманітних уміннях, цінностях i переконаннях, вольових якостях особистості (Пустовіт, Пруцакова, Руденко й Колонькова, 2008, с. 10). 
У своєму дослідженні ми дотримуємося діяльнісного підходу, уважаючи поняття «екологічна культура» більш широким, ніж поняття «екологічна компетентність». Під поняттям «екологічна компетентність майбутнього вчителя Нової української школи» будемо вважати «інтегративну характеристику його особистості, що являє собою системну цілісність набутих екологічних цінностей, засвоєних екологічних знань, способів діяльності з вивчення і дослідження явищ, об'єктів і процесів навколишнього середовища, реалізації функцій екологічної освіти у професійній діяльності без порушення рівноваги в системі «суспільство природа» (Логвінова, 2014).

При визначенні структури професійної компетентності вчителя Нової української школи ми будемо виходити 3 того, що всі різновиди компетентностей, у тому числі й екологічна, є видовими поняттями по відношенню до родового поняття «компетентність», i мають однакову структуру, яка включає когнітивний, діяльнісний i особистісномотиваційний компоненти. Зупинимося на характеристиці цих компонентів більш докладно.

Так, когнітивний компонент містить систему екологічних знань, пов'язаних із навколишнім середовищем, що визначають екоцентричний світогляд і виражаються у світосприйнятті, світовідчутті й світорозумінні людини, в основу яких покладена ідея оптимізації відносин між людиною і природою. Діяльнісний компонент пов'язаний з опануванням студентами аналітичних, прогностичних, дослідницьких та оцінювальних умінь. Особистісно-мотиваційний компонент розглядається як один 3 основних складників екологічної компетентності майбутніх учителів початкової школи, яка передбачає ціннісне ставлення до природи, розуміння необхідності їі збереження, мотивацію екологічної й природоохоронної діяльності та здатність до рефлексії.

Набуття майбутніми вчителями Нової української школи природничо-наукових i екологічних компетентностей, які мають безпосереднє відношення до формування в них екологічної культури, повинно бути підпорядковано зміні рівня сприйняття ними навколишньої дійсності, з іiі осмисленням і вербалізацією (понятійним обгрунтуванням) щодо майбутньої професійної діяльності, формуванням практичного відношення до знань, прагненням до їх поглиблення, удосконалення для подальшого застосування на посаді вчителя. 
Відповідно до рівня сприйняття навколишнього світу змінюється розуміння значущості набутих знань, які тепер повинні виконувати об’єднувальну функцію 3 професійними психолого-педагогічними знаннями в їх взаємозв'язках і взаємовідношеннях.

У майбутніх учителів Нової української школи у процесі навчання відбувається усвідомлення власних дій із позиції їх мети, засобів виконання, здійснюваних операцій, очікуваного результату, можливих побічних наслідків діяльності, ймовірних труднощів і перешкод на шляху отримання запланованого результату. Вербалізація їхньої діяльності виражається в можливості описати екологічні явища, процеси, обставини за допомогою понять, здатності пояснити власні дії, передати свій досвід, навчати інших. Це, своєю чергою, активізує процеси свідомої регуляції діяльності, сприяє визначенню іiі умов і принципів.

Прагнення до класифікації та систематизації знань об'єктів і явищ навколишнього середовища, осмислення та вербалізації діяльності спонукає до об'єктивного самооцінювання наявних знань, усвідомлення недоліків і прогалин у них, прагнення їх усунути. Це, з однієї сторони, активізує самоосвітню діяльність особистості, а з другої - стимулює формування ціннісного ставлення до екологічних знань.

Компоненти екологічної компетентності майбутніх учителів Нової української школи виявляються в кількох узаємопов'язаних аспектах: пояснювально-аналітичному, прогностичному, процесуальному, діяльнісному, ціннісно-орієнтаційному (Гурняк, 2008). Так, пояснювально-аналітичний аспект передбачає: можливість установлення взаємозв'язку між набутими знаннями 3 різних галузей наук та екологічною ситуацією; здатність пов'язати наявні знання про природні об'єкти та явища з їх властивостями; уміння пояснити природний процес i показати розуміння понять, принципів або закономірностей, що лежать у його основі; здатність провести аналіз екологічної проблеми і встановити напрями ії розв'язання.

Прогностичний аспект полягає в можливості: передбачити шляхи розвиту подій, результатів власної діяльності; прогнозувати наслідки зміни умов навколишнього середовища на екологічний складник у природних $\mathrm{i}$ штучних системах; розуміти екологічні причинно-наслідкові зв'язки; усвідомлювати особисту відповідальність в організації освітнього процесу, спрямованого на формування екологічного мислення учнів.

3 прогностичним аспектом пов'язана регуляція майбутніми вчителями Нової української школи особистої діяльності: обрання найбільш 
оптимальних за даних умов методичних прийомів або стратегії дій, оцінювання правильності прийнятого рішення, можливість зробити висновки на основі отриманих даних або фактів та поширити їх на нові ситуації.

Процесуальний аспект екологічної компетентності передбачає можливість знаходження процедури або способу діяльності, придатних для розв’язання проблеми. Для майбутнього вчителя Нової української школи він включає в себе: усвідомлення існування проблеми і прагнення іï розв'язати; формулювання гіпотези і планування заходів із іiі перевірки; створення та пояснення стратегій розв'язання проблеми; обрання методів, засобів і технологій екологічної діяльності; оцінювання та самооцінювання результатів екологічної діяльності, порівняння їх із запланованими.

Діяльнісний аспект полягає у виконанні практичних дій, що пов'язані з реальними екологічної освіти і виховання учнів, проведенні наукового дослідження. При цьому етапами діяльності $\epsilon$ : постановка мети; формулювання запитань і гіпотез; складання плану дій, його реалізація; отримання даних, їх аналіз і тлумачення; формулювання висновків; представлення отриманих результатів. Він втілюється переважно в ході проектної й наукової діяльності майбутніх учителів Нової української школи.

Ціннісно-орієнтаційний аспект прояву екологічної компетентності виявляється у ставленні майбутніх учителів Нової української школи до екологічних процесів i проблем, усвідомленні їх важливості, узаємообумовленості, готовність керуватися знаннями у професійній діяльності; формування власного погляду щодо значущості екологічних знань, їх ролі в житті людини і стратегї сталого розвитку сучасного суспільства. Важливою і неодмінною умовою реалізації компетентнісного підходу в екологічній освіті майбутніх учителів Нової української школи є їхня власна активна діяльність, що має вирішальне значення в розвитку особистості, становленні системи цінностей.

На підставі визначення основних характеристик екологічної компетентності, аспектів іiі прояву нами розроблено систему завдань i вправ, що спрямовані на набуття майбутніми вчителями Нової української школи вмінь професійної діяльності в цій галузі.

Розповідь, пояснення, бесіда, лекція хоча і забезпечують передачу за короткий час великого обсягу інформації, проте вони є малоефективними в аспекті набуття майбутніми вчителями Нової української школи екологічної компетентності. Діяльнісний підхід передбачає застосування активних та інтерактивних методів навчання, за допомогою яких студенти 
відходять від позиції спостерігачів, споживачів навчальної інформації, стають активними учасниками освітнього процесу. Самостійність, ініціативність, творчість студентів забезпечують розв'язування творчих, проблемних завдань, завдань практичного спрямування, аналіз життєвих ситуацій, проведення навчального дослідження.

Застосування на заняттях системи практико зорієнтованих завдань i вправ виступає одним із шляхів реалізації діяльнісного підходу в екологічній освіті й у той самий час забезпечує підвищення ефективності освітнього процесу. При цьому механічне запам'ятовування замінюється логічним, матеріал розглядається в різних узаємозв'язках, засвоюються не окремі факти, а цілісна система знань. Виконання завдань i вправ забезпечує свідоме й міцне засвоєння програмового матеріалу, спонукає майбутніх учителів Нової української школи до застосування знань, пошуку умов і меж їх упровадження, перетворення, доповнення, розгляд у нових моделях і контекстах тощо. На етапі узагальнення та систематизації знань доцільно застосовувати проблемні екологічні завдання практичного спрямування, завдання творчого характеру, завдання на застосування набутих умінь і навичок у нових умовах. Система завдань і вправ повинна передбачати поступове ускладнення завдань, бути посильною для виконання більшістю студентів, забезпечувати усвідомлення ними мети, змісту завдання та етапів виконання, можливість постійного контролю й оцінювання результативності роботи.

При регулярному застосуванні на заняттях системи екологічних навчальних завдань із подальшою самоперевіркою або взаємоперевіркою студенти будуть поінформовані про те, наскільки успішно відбувається процес засвоєння екологічного матеріалу, бачитимуть проміжні результати власного навчання, шляхом самооцінювання визначатимуть, чи відповідають вони їхньому бажанню і очікуванню, чи мають бути поліпшені.

Застосування системи творчих, екологічно зорієнтованих практичних завдань забезпечує стимулювання систематичної праці студентів, посилення мотиваційного компоненту.

Вимогам діяльнісного підходу відповідають завдання, які стимулюють майбутніх учителів Нової української школи до аналізу конкретних екологічних ситуацій, потребують формулювання гіпотез, розв'язання проблем, визначення причинно-наслідкових зв'язків, планування діяльності, аналізу даних і формулювання висновків на ї основі, прийняття рішень. Окрім того, важливо, щоб завдання та вправи 
були різноманітними як за змістом, так і за формою подачі, викликали цікавість, містили як закриті, так і відкриті запитання, мали практичну спрямованість, поєднували набуті професійні знання 3 базовими екологічними поняттями, спонукали до застосування екологічних знань при розв'язанні різноманітних проблем і ситуацій.

Наведемо приклад завдання, що спрямоване на набуття пояснювально-аналітичного аспекту екологічної компетентності (рис. 1).

Креативна екологічна задача «Як коти підвищують надої молока?»

Якось селяни запитали в ученого Чарльза Дарвіна, як збільшити надої корів? Дарвін жартівливо порадив їм придбати котів. Чому так відповів учений? Підказкою є харчовий ланцюг, який складається 3 таких живих організмів:

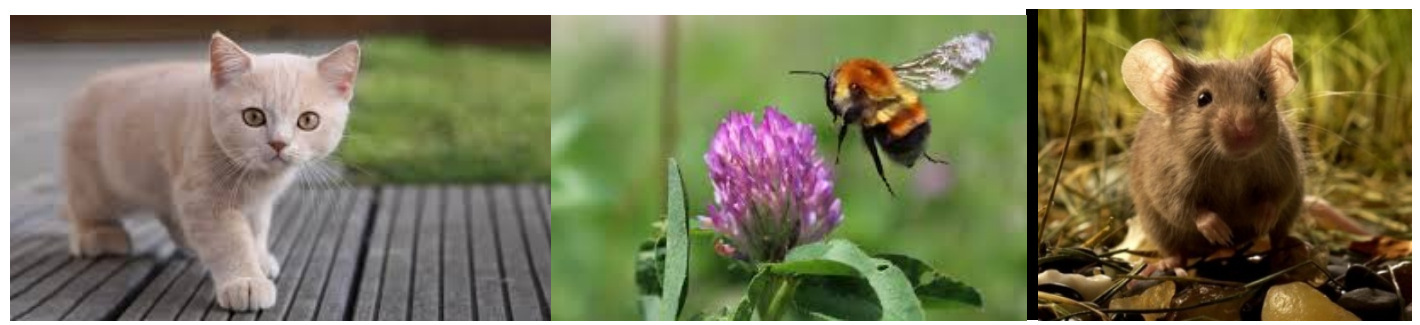

Рис. 1. Приклад завдання, що спрямоване на набуття пояснювально-аналітичного аспекту екологічної компетентності

У силу своєї міжпредметності й інтегративності компетентнісні завдання сприяють систематизації предметних знань на діяльнісній, практико зорієнтованій основі. У той самий час, учні оволодівають універсальними способами освітньої діяльності, вирішують значущі особистісні, екологічні, природничі проблеми з застосуванням предметних знань, тому компетентні задачі можуть виступати як поштовх до розвитку мотивації учнів до екологічної діяльності. Процес рішення компетентнісної задачі завжди передбачає «вихід» учня за межі освітнього процесу, у простір соціальних, екологічних, валеологічних та інших проблем.

Наведемо приклад завдання, спрямованого на набуття прогностичного аспекту екологічної компетентності.

Ділова гра «Що ми візьмемо для польоту на іншу планету?» Сформуйте список згідно 3 потребами підтримки життя екіпажу та дослідження планет.

Наведемо приклад завдання, спрямованого на набуття процесуального аспекту екологічної компетентності.

Запропонуйте і розробіть екологічний проєкт, що спрямований на формування бережливого ставлення до води в кожній родині. 
Наведемо приклад завдання, спрямованого на набуття результативно-діяльнісного аспекту екологічної компетентності.

Ви можете здійснити справжнє екологічне дослідження, використовуючи вапняну воду. Для іï приготування в невелику посудину слід насипати гашеного вапна (воно використовується при побілці приміщень і дерев, входить до складу бордоської суміші), залити його чистою водою по вінця посудини, щільно закрити іiі та залишити на ніч. Наступного дня злийте прозорий розчин над осадом. Це і є вапняна вода. Прозора вапняна вода, залишена у відкритій посудині з часом мутніє внаслідок розчинення в ній вуглекислого газу повітря. 3'ясуйте, за який час помутніє вапняна вода в закритому приміщенні, на відкритому повітрі, на узбіччі дороги, у лісі. Для того, щоб точно виявити початок помутніння, спостереження слід проводити на темному фоні, наприклад, помістивши за склянкою з вапняною водою чорний листок паперу. Сплануйте і проведіть дослід, опишіть його хід. Яке практичне значення може мати дане екологічне дослідження? Що вам відомо про зміну концентрації вуглекислого газу в сучасному світі та їі вплив на навколишнє середовище?

Наведемо приклад завдання, спрямованого на набуття иіннісноорієнтаційного аспекту екологічної компетентності.

У сучасному світі понад 500 млн. автомобілів. На їх частку припадає біля 60 \% усіх викидів у атмосферу. Найперше, це чадний газ $\mathrm{CO}$, оксиди Нітрогену, Сульфуру, сполуки Плюмбуму. Запропонуйте шляхи або пригадайте вже відомі, якими можна значно зменшити кількість шкідливих речовин у вихлопних газах автомобіля. Обгрунтуйте необхідність таких екологічних дій. Як кожен із нас може сприяти збереженню чистоти повітря?

За показники сформованості екологічної компетентності майбутнього вчителя Нової української школи нами прийнято: знання екологічних понять; здатність пояснювати екологічні процеси в довкіллі; здатність передбачати екологічні зміни середовища при антропогенному навантаженні; здатність пропонувати практичні дії, що спрямовані на збереження довкілля; володіння професійними методами для проведення екологічної освіти і виховання учнів; володіння сучасними технологіями для проведення еколого-просвітницької діяльності; розуміння особистої відповідальності за екологічний стан довкілля.

Для проведення експериментального дослідження 3 визначення сформованості екологічної компетентності майбутнього вчителя Нової української школи шляхом застосування в освітньому процесі системи 
практико зорієнтованих завдань і вправ екологічного спрямування обрано групи студентів третього і четвертого курсів денної форми навчання спеціальності 013 «Початкова освіта» Черкаського національного університету імені Богдана Хмельницького (усього близько 80 осіб). За результатами тестування, самооцінювання, анкетування отримано дані до початку експериментального впровадження в освітній процес практико зорієнтованих завдань і вправ екологічного спрямування, які стимулюють студентів до аналізу конкретних екологічних ситуацій, потребують формулювання гіпотез, розв'язання проблем, визначення причиннонаслідкових зв'язків, планування діяльності, аналізу даних i формулювання висновків на їх основі, прийняття рішень (3-й курс) і після (4-й курс). Оцінювання проводилося в балах за шкалою від 1 до 10 (рис. 2):

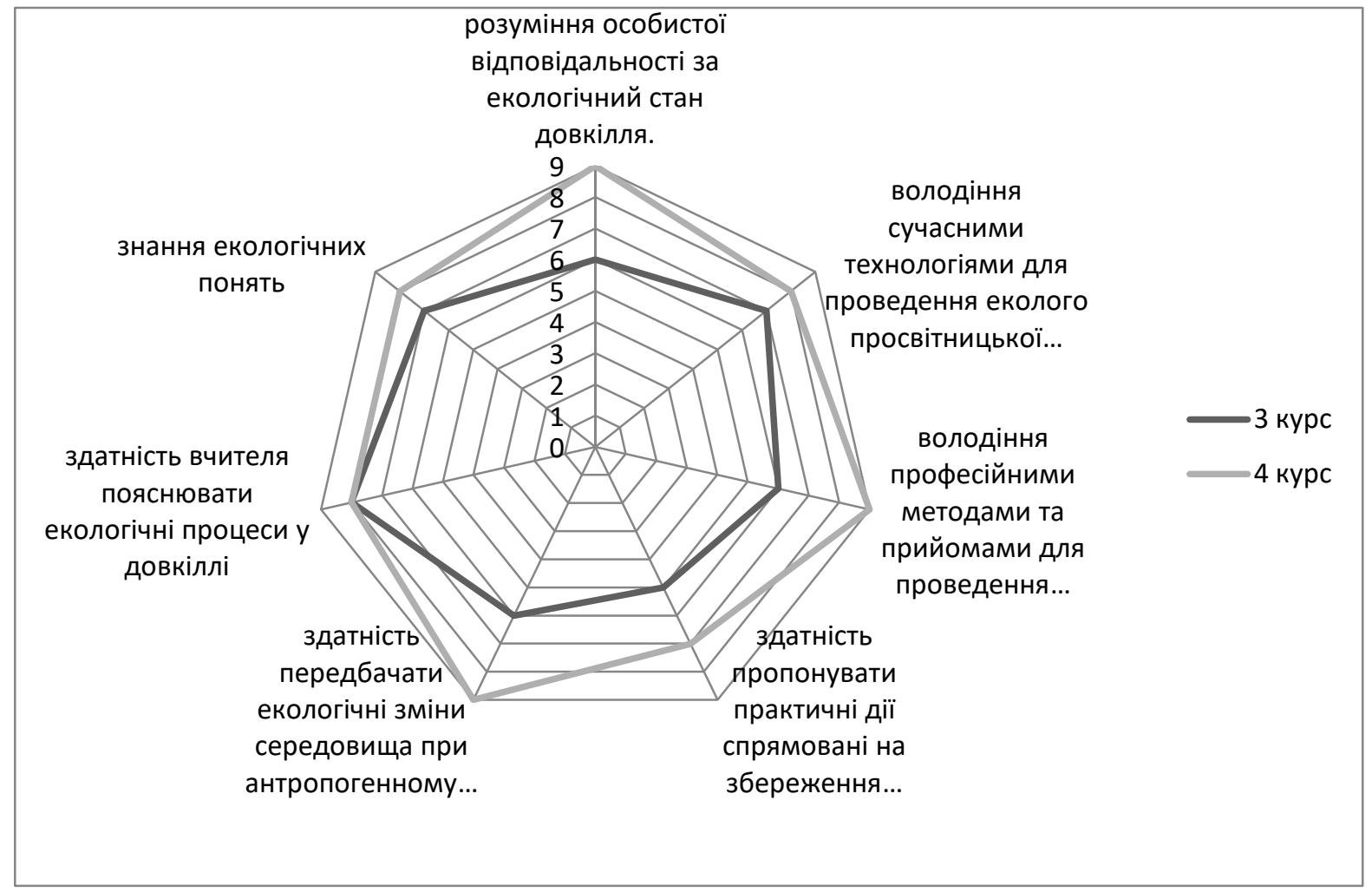

Рис. 2. Пелюсткова діаграма зміни показників екологічної компетентності (діяльнісний підхід) студентів 3-х і 4-х курсів

Як бачимо з рисунку, найкраще студентам третього курсу дається пояснення екологічних процесів у довкіллі, володіння екологічними поняттями i сучасними технологіями проведення еколого-просвітницької роботи. Натомість високих результатів у формуванні екологічної компетентності у студентів четвертого курсу досягнуто за іншими показниками: розуміння особистої відповідальності за екологічний стан довкілля; здатність 
передбачати екологічні зміни середовища при антропогенному втручанні; оволодіння методами проведення екологічних досліджень.

Висновки. Отже, проведений теоретичний аналіз наукової літератури дає підстави стверджувати, що проблема формування екологічної компетентності майбутніх учителів нині більш активно розробляється вітчизняними вченими, ніж зарубіжними. Організована на базі кафедри початкової освіти Черкаського національного університету імені Богдана Хмельницького експериментальна робота підтверджує можливість формування екологічної компетентності в майбутніх учителів Нової української школи шляхом застосування в освітньому процесі системи практико зорієнтованих завдань і вправ екологічного спрямування.

Доцільність вибору в ході дослідження діяльнісного підходу підтверджено показниками процесуального (передбачає можливість знаходження процедури або способу діяльності, придатних для розв'язання екологічної проблеми) і діяльнісного (втілюється переважно в ході проектної та наукової діяльності) аспектів.

Перспективи подальших розвідок нам вбачаються в розширенні змісту силабусів навчальних дисциплін «Основи природознавства» та «Методика навчання природничої освітньої галузі» для вдосконалення екологічної освіти майбутніх учителів Нової української школи завдяки розширення спектру екологічних знань, розвитку екологічного світогляду, формування екологічного мислення, оволодіння екологічною етикою та екологічною культурою. 


\section{СПИСОК ЛІТЕРАТУРИ}

Александрович, Н. О. (2011). Формування екоетичної позиції майбутнього вчителя як актуальна соціально-педагогічна проблема. Засоби навчальної та науководослідної роботи, 35, 5-9.

Бойченко, С. В. і Саєнко, Т. В. (2013). Екологічна освіта - основа сталого розвитку суспільства. Проблеми і перспективи вищої школи. Київ: Університет "Україна".

Бойчук, Ю. Д. (2010). Особистісні якості як найважливіший складник екологовалеологічної культури майбутнього вчителя. Засоби навчальної та науководослідної роботи, 32, 6-11.

Глухов, І. Г. (2011). Сутність еколого-правових знань майбутнього вчителя. Засоби навчальної та науково-дослідної роботи, 35, 17-21.

Граматик, Н. В. (2016). Категорія екологічної відповідальності в світлі сучасних наукових досліджень. Наукові записки Ніжинського державного університету ім. Миколи Гоголя. Психолого-педагогічні науки, 2, 27-31.

Граматик, Н. (2017). Природнича підготовка майбутніх учителів початкових класів у параметрах сучасної психолого-педагогічної науки. Educational and Philological Sciences, 1, 224-227.

Гурняк, I. А. (2008). Методика реалізаиії компетентнісного підходу в процесі навчання хімії. Суми : СумДПУ ім. А. С. Макаренка.

Концепція екологічної освіти України : Рішення колегії МОН № 13/6-19 від 20.12.2001. URL: https://zakon.rada.gov.ua/rada/show/v6-19290-01

Крамаренко, А. М. (2015). Еколого орієнтована освіта майбутніх учителів початкової школи : теоретико-практичний аспект. Наукові записки Вінниџького державного педагогічного університету імені Михайла Кочююбинського. Серія : Педагогіка $i$ психологія, 44, 287-292.

Курняк, Л. Д. (2006). Екологічна культура : поняття і реальність. Вища освіта України, $3,32-37$.

Лернер, И. Я. (1981). Дидактические основы методов обучения. Москва : Педагогика.

Логвінова, Я. О. (2014). Формування екологічної компетентності майбутнього викладача біології в процесі вивчення природничих дисциплін. (Автореферат дис. ... канд. пед. наук). Кіровоград.

Нінова, Т. С. (2017). Динаміка формування екологічної свідомості майбутніх учителів початкової школи у процесі професійної підготовки. Вісник Черкаського університету. Серія Педагогічні науки, 13-14, 120-130.

Пустовіт, Н., Пруцакова, О. та Колонькова, О. (2014). Школа екологічного вчинку. Кіровоград : Імекс-ЛТД.

Пустовіт, Н. А., Пруцакова, О. Л., $\quad$ Руденко, Л. Д. $\quad$ і $\quad$ Колонькова, О. О. (2008). Формування екологічної компетентності школярів. Київ: Педагогічна думка.

Хоботова, Е. Б., Уханьова, М. І., Даценко, В. В. та Сгорова, Л. М. (2010). Удосконалення екологічної освіти в Україні. Засоби навчальної та науководослідної роботи, 32, 143-149. 
Хроленко, М. В. (2007). Формування екологічної свідомості майбутніх вчителів початкових класів. (Автореферат дис. ... канд. пед. наук). Київ: Національний педагогічний ун-т ім. М. П. Драгоманова.

Judson, G. (2014). The Role of Mental Imagery in Imaginative and Ecological Teaching. Canadian Journal of Education, 37(4). Retrieved from: http://journals.sfu.ca/cje/index.php/cje-rce/article/view/1725

Rigolon, A. (2012). The school environment as a teacher: The role of space and place in enhancing ecological literacy and social competence development in children and young people. Retrieved from: https://clc.am/rI1nMA

\section{REFERENCES}

Aleksandrovich, N. O. (2011). Formuvannia ekoetychnoi pozytsii maibutnoho vchytelia yak aktualna sotsialno-pedahohichna problema [Formation of eco-ethical position of the future teacher as a topical socio-pedagogical problem]. Zasobi Navčal'noj ta NaukovoDoslidnoï Roboti [Means of educational and research work], 35, 5-9. [in Ukrainian]

Boychenko, S. V. \& Sayenko, T. V. (2013). Ekolohichna osvita - osnova staloho rozvytku suspilstva. Problemy i perspektyvy vyshchoi shkoly [Environmental education is the basis for sustainable development of society. Problems and Prospects of Higher Education]. Kyiv: Universytet "Ukraina". [in Ukrainian]

Boychuk, Yu. D. (2010). Osobystisni yakosti yak naivazhlyvishyi skladnyk ekolohovaleolohichnoi kultury maibutnoho vchytelia [Personal qualities as the most important component of the future teacher's ecological-valeological culture]. Zasobi Navčal'noj ta Naukovo-Doslidnoï Roboti [Means of educational and research work], 32, 6-11. [in Ukrainian]

Gluhov, I. G. (2011). Sutnist ekoloho-pravovykh znan maibutnoho vchytelia [The essence of environmental legal knowledge of the future teacher]. Zasobi Navčal'noj ta NaukovoDoslidnoï Roboti [Means of educational and research work], 35, 17-21. [in Ukrainian]

Gramatik, N. V. (2016). Katehoriia ekolohichnoi vidpovidalnosti v svitli suchasnykh naukovykh doslidzhen [The category of environmental responsibility in light of current scientific research]. Naukovi zapysky Nizhyns'koho derzhavnoho universytetu im. Mykoly Hoholya. Psykholoho-pedahohichni nauky [Scientific Notes of Nizhyn State University. Nicholas Gogol. Psychological and pedagogical sciences], 2, 27-31. [in Ukrainian]

Gramatik, N. (2017). Pryrodnycha pidhotovka maibutnikh uchyteliv pochatkovykh klasiv u parametrakh suchasnoi psykholoho-pedahohichnoi nauky [Natural training of future primary school teachers in the parameters of modern psychological and pedagogical science]. Educational and Philological Sciences], 1, 224-227. [in Ukrainian]

Gurnyak, I. A. (2008). Metodyka realizatsii kompetentnisnoho pidkhodu v protsesi navchannia khimii [Methodology of realization of the competence approach in the process of teaching chemistry]. Sumy : SumDPU im. A. S. Makarenka. [in Ukrainian]

Kontseptsiya ekolohichnoyi osvity Ukrayiny [The concept of environmental education in Ukraine]: Rishennya kolehiyi MON za N 13/6-19, 20.12.2001. URL: https://zakon.rada.gov.ua/rada/show/v6-19290-01. 
Kramarenko, A. M. (2015). Ekoloho oriientovana osvita maibutnikh uchyteliv pochatkovoi shkoly: teoretyko-praktychnyi aspekt [Ecologically oriented education of prospective elementary school teachers: theoretical and practical aspects]. Naukovi zapysky Vinnyts'koho derzhavnoho pedahohichnoho universytetu imeni Mykhayla Kotsyubyns'koho. Seriya: Pedahohika i psykholohiya [Scientific notes of Vinnytsia State Pedagogical University named after Mikhail Kotsyubynsky. Series: Pedagogy and Psychology], 44, 287-292. [in Ukrainian]

Kurnyak, L. D. (2006). Ekolohichna kultura: poniattia i realnist [Ecological culture: concept and reality] Vyshcha osvita Ukrayiny [Higher education in Ukraine], 3, 32-37. [in Ukrainian]

Lerner, I. Ya. (1981). Didakticheskiye osnovy metodov obucheniya [Didactic foundations of teaching methods]. Moskva: Pedagogika. [in Russian]

Logvinova, Ya. O. (2014). Formuvannia ekolohichnoi kompetentnosti maibutnoho vykladacha biolohii $v$ protsesi vyvchennia pryrodnychykh dystsyplin [Formation of ecological competence of the future biology teacher in the process of studying natural sciences]. (Avtoreferat dys. ... kand. ped. nauk). Kirovohrad. [in Ukrainian]

Ninova, T. S. (2017). Dynamika formuvannia ekolohichnoi svidomosti maibutnikh uchyteliv pochatkovoi shkoly u protsesi profesiinoi pidhotovky [Dynamics of formation of environmental awareness of future primary school teachers in the process of vocational training]. Visnyk Cherkas'koho universytetu. Seriya Pedahohichni nauky [Bulletin of the Cherkasy Bohdan Khmelnytsky National University. Series «Pedagogical Sciences»], 13-14, 120-130. [in Ukrainian]

Pustovit, N., Prutsakova, O. \& Kolonkova, O. (2014). Shkola ekolohichnoho vchynku [Environmental Action School]. Kirovohrad: Imeks-LTD. [in Ukrainian]

Pustovit, N. A., $\quad$ Prutsakova, O. L., $\quad$ Rudenko, L. D. \& Kolon'kova, O. O. (2008). Formuvannia ekolohichnoi kompetentnosti shkoliariv [Formation of ecological competence of schoolchildren]. Kyiv: Pedahohichna dumka. [in Ukrainian]

Khobotova, E. B., $\quad$ Ukhanova, M. I., $\quad$ Datsenko, V. V. \& Yehorova, L. M. (2010). Udoskonalennia ekolohichnoi osvity v Ukraini [Improving environmental education in Ukraine]. Zasobi Navčal'noj ta Naukovo-Doslidnoï Roboti. [Means of educational and research work], 32, 143-149. [in Ukrainian]

Hrolenko, M. V. (2007). Formuvannia ekolohichnoi svidomosti maibutnikh vchyteliv pochatkovykh klasiv [Formation of environmental awareness of future primary school teachers]. (Avtoreferat dys. ... kand. ped. nauk). Kyiv: Natsional'nyy pedahohichnyy un-t im. M. P. Drahomanova. [in Ukrainian]

Judson, G. (2014). The Role of Mental Imagery in Imaginative and Ecological Teaching. Canadian Journal of Education, 37(4). Retrieved from: http://journals.sfu.ca/cje/index.php/cje-rce/article/view/1725

Rigolon, A. (2012). The school environment as a teacher: The role of space and place in enhancing ecological literacy and social competence development in children and young people. Retrieved from: https://clc.am/rI1nMA. 


\section{Шпак Валентина Павлівна}

доктор педагогічних наук, професор, завідувач кафедри початкової освіти Черкаського національного університету імені Богдана Хмельницького

каб. 254, вул. Остафія Дашковича, 24, Черкаси, Україна 18001

Тел. +38(068) 7109710

ORCID ID 0000-0003-0913-6150

e-mail: shpakvalentina64@gmail.com

Нінова Тетяна Степанівна

кандидат педагогічних наук, доцент кафедри початкової освіти Черкаського національного університету імені Богдана Хмельницького

каб. 254, вул. Остафія Дашковича, 24, Черкаси, Україна 18001

Тел. +38(097) 2618162

ORCID ID 0000-0002-7499-6862

e-mail: ninova@ukr.net

\author{
Shpak Valentina \\ Doctor of Pedagogical Sciences, \\ Professor, Head of the Primary Education \\ Department, Bohdan Khmelnytsky \\ National University at Cherkasy \\ Room 254, 24, Ostafiya Dashkovicha Str, \\ Cherkasy, Ukraine 18001 \\ Тел. +38(068) 7109710 \\ ORCID ID 0000-0003-0913-6150 \\ e-mail: shpakvalentina64@,gmail.com \\ Ninova Tetiana \\ candidate of Pedagogical Sciences, docent \\ of the Primary Education Department, \\ Bohdan Khmelnytsky National University \\ at Cherkasy \\ Room 254, 24, Ostafiya Dashkovicha Str, \\ Cherkasy, Ukraine 18001 \\ Тел. +38(097) 2618162 \\ ORCID ID 0000-0002-7499-6862 \\ e-mail: ninova@ukr.net
}

